\section{M alignant giant cell type fibrohistiocitom of the abdominal wall}

Mitrovic Nebojsa, Mitrovic Aleksandar

Department of Surgery, Clinical Hospital center Zemun, Belgrade, Serbia

\section{A bstract}

Malignant fibrous histiocytoma is a condition involving a tumor of the bone or soft tissues. The tumor often appears in the legs or arms, but it can develop in other parts of the body. The disease is the most common soft tissue cancer that is diagnosed in older adults, and is often diagnosed in people between the ages of 50 and 70 . We present a case of giant cell malignant fibrohistiocytoma of the abdominal wall. A 77 year old woman was admitted for further evaluation and treatment of tumor in the right ingvinal region of the abdominal wall. She claimed that tumor have appeared 3 mounths earlier and it was characterized by rapid growth and tenderness. NMR demonstrated expansive heterogeneous mass, $18,6 \times 16,2 \mathrm{~cm}$ of diameter. We performed total extirpation of the tumor. Postoperative period was uncomplicated and she was discharged from the hospitaly in good condition. Pathohystological examination confirmed malignant fibrous histiocytoma. Depending on the stage of disease and the depth of invasion by the tumor, surgical resection is the treatment of choice. Radiotherapy, chemotherapy, and immunotherapy are other therapeutic modalities. Long term followup with regular chest X-rays and CT scans of the abdomen to detect tumor recurrence, metastasis and any lymph node involvement are mandatory.

Keywords: malignant fibrous histiocytoma, anterior abdominal wall, soft tissue

\section{Maligni fibrohistiocitom tipa džinovskih ćelija prednjeg trbušnog zida}

\author{
Mitrović Nebojša, Mitrović Aleksandar \\ Klinika za hirurgiju, Kliničko-bolnički centar Zemun, Beograd, \\ Srbija
}

\section{Apstrakt}

Maligni fibrohistiocitom je tumor koji napada kosti ili meka tkiva. Najčešće se pojavljuje na nogama ili rukama, ali može da se razvije i u drugim delovima tela. Ovaj tumor je najčešći dijagnostikovani karcinom mekih tkiva kod starijih odraslih i najčešće se dijagnostikuje kod ljudi između 50 i 70 godina. Mi predstavljamo slučaj malignog fibrohistiocitoma tipa džinovskih ćelija prednjeg trbušnog zida. Pacijentkinja stara 77 godina primljena je u bolnicu radi dijagnostike i lečenja tumorske promene $u$ desnoj ingvinalnoj regiji prednjeg trbušnog zida. Navodi da se promena javila 3 meseca pre pregleda i da je karakterišu rapidni rast i bolna osetljivost. NMR pregled trbuha pokazao je ekspanzivnu heterogenu masu veličine $18,6 \times 16,2 \mathrm{~cm}$. Izveli smo totalnu ekstirpaciju tumorske promene. Pacijentkinja je nakon nekomplikovanog postoperativnog perioda otpuštena iz bolnice u dobrom opštem stanju. Patohistološka analiza operativnog materijala pokazala je da se radi o malignom fibrohistiocitomu. U zavisnosti od faze bolesti i dubine invazije tumora hirurška resekcija je metoda terapijskog izbora. Radioterapija, hemioterapija i imunoterapija su drugi terapijski moduliteti. Dugoročno praćenje sa redovnom Rtg i CT dijagnostikom za otkrivanje rekurentnosti, metastaza i zahvatanja limfnih čvorova je obavezno.

Ključne reči: maligni fibrozni histiocitom, prednji trbušni zid, meka tkiva

\title{
Introduction
}

Malignant fibrous histiocytoma, a type of sarcoma, is a malignant neoplasm of uncertain origin that arises both in soft tissue and bone. MFH of soft tissue typically presents in a patient that is approximately 50 to 70 years of age though it can appear at any age. There is a slight male predominance ${ }^{1}$. Soft tissue MFH can arise in any part of the body but most commonly in the lower extremity, especially the thigh. Other common locations include the upper extremity and retroperitoneum. Patients often complain of a mass or lump that has arisen over a short period of time ranging from weeks to months. The mass does not usually cause any pain unless it is compressing a nearby nerve. Symptoms such as weight loss and fatigue are not typical but can present in patients with advanced disease ${ }^{2}$. Retroperitoneal tumors can become quite large 
before they are detected as patients do not feel a mass per se but rather associated constitutional symptoms such as anorexia or increased abdominal pressure ${ }^{3}$.

MFH manifests a broad range of histologic appearances with five sub-types described (Table 1.) ${ }^{4}$

Procedures and tests that healthcare provides use to make a diagnosis include X-rays, Computer tomography (CT) scan, Magnetic resonance imaging (MRI) scan, Bone scan and Biopsy 5 . Once the diagnosis of MFH has been comfired, an individual treatment plan is made for each patients. Sarcoma treatment requires a multimoidality approach and hence a team of physicians will participate in a patient's care. There are essentially three main types of treatment that will need to be coordinated to treat the MFH: Surgery, Radiation and Chemotherapy ${ }^{6}$. Prognostic factors that are known to correlate with survival in patients with MFH include tumor grade, depth, size, metastatic status, patient's age and histological subtype ${ }^{7}$.

\section{Case report}

A 77-year-old female patient was admitted to the hospital due to tumor in the right ingvinal region of the abdominal wall with central necrosis of skin (Figure 1. and Figure 2.), which the patient claimed to have appeared 3 months earlier. She also claimed that it was characterized by rapid growth and tenderness. Blood count and blood chemistry were within normal range.

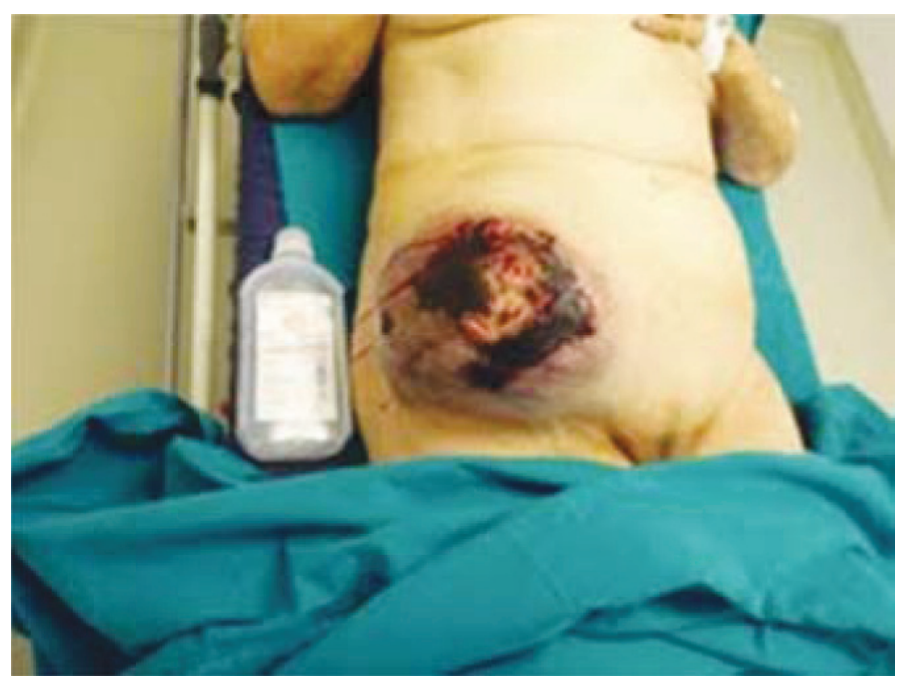

Figure 1. Right ingvinal region of the abdominal wall with tumor

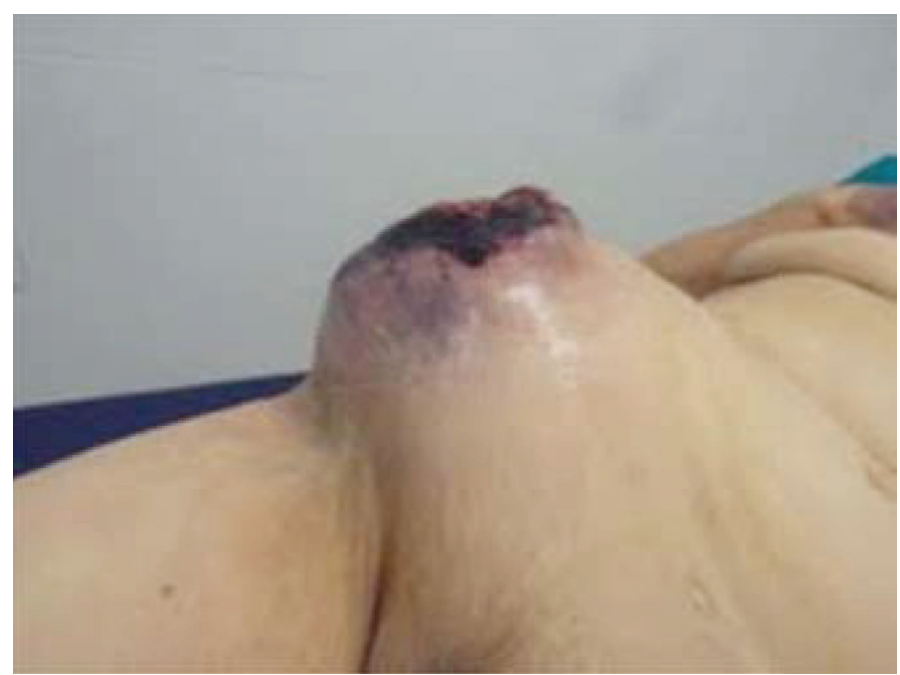

Figure 2. Right ingvinal region of the abdominal wall with central necrosis of skin 
NMR examination (Figure 3.) of the pelvis verified that it was expansive heterogeneous mass with the largest diameter of $186 \mathrm{~mm} \times 162 \mathrm{~mm}$ located in the right groin, in the subcutaneous tissue. The mass put pressure on the front-lateral abdominal wall andlaterally compressed tissue. There was no clear delineation of the oblique abdominal muscle. Femoral artery and vein were behind the tumor, without direct contact. Given the findings, it was decided to do the surgical treatment of these changes.

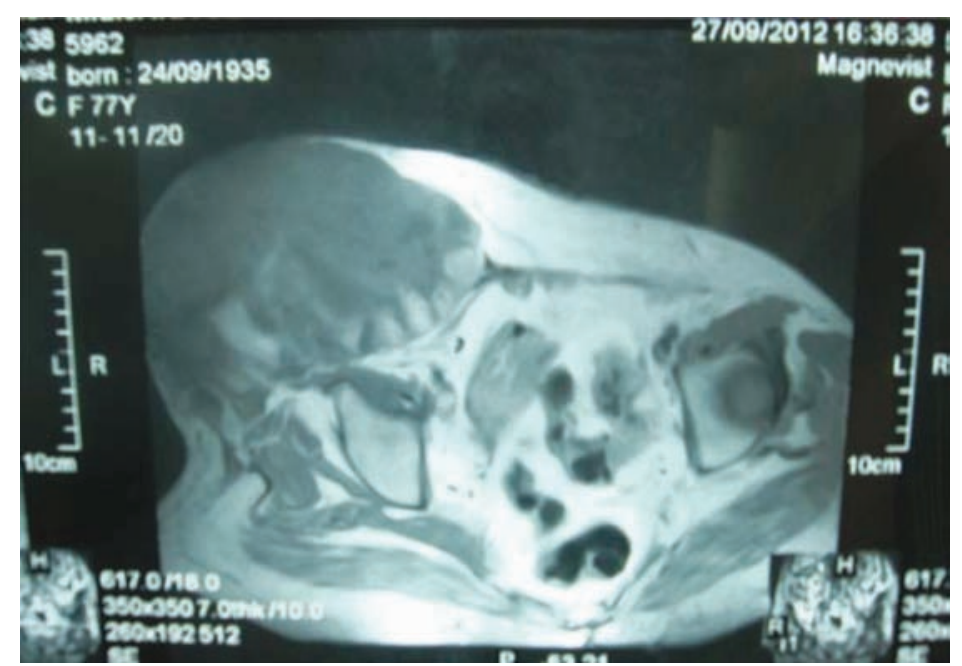

Figure 3. Expansive heterogeneous mass with the largest diameter of 186mmx162mm (NMR examination)

\section{Surgical treatment and findings}

After adequate preoperative preparation the patient underwent surgery. An elliptical incision was made to cut the skin and subcutaneous tissue around tumor borders.

Preparation of tumor borders was done followed by partial resection of fascias m.externus abdominis and m.internus abdominis, and after hemostatic control extirpation of the tumor was done. The size of tumor was $25 \times 30 \mathrm{~cm}$ (Figure 4.).. The extirpation of the tumor was done partly through manual digitoklasis, partly through thermocauter. The tumor was macroscopically partly necrotised with fields with purulent secernation, and partly was encapsulated. Elements of the Scarpa's triangle were prepared, and there was no evidence of infiltration a or $\mathrm{v}$ femoralis. Tumor and the surrounding tissue samples were sent to HP analysis in order to confirm the possible tumor dispersion. Lavage was done after checking hemostasis, 2 Redon drains were placed, and surgical wound was reconstructed in layers.

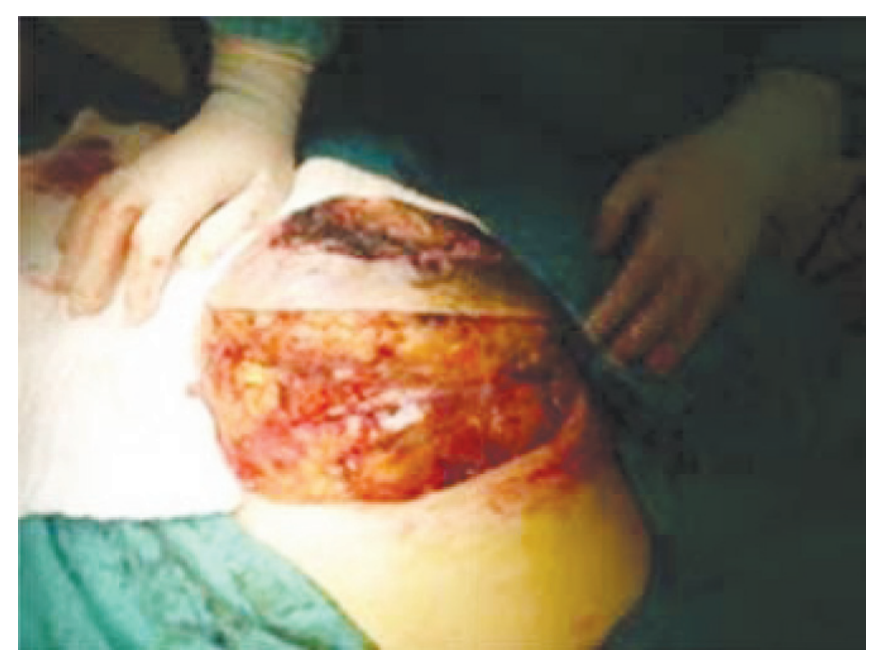

Figure 4. The size of tumor was $25 \times 30 \mathrm{~cm}$ 


\section{Postoperative course}

The patient Early postoperative course of spends in the ICU where significant decline in CSF was recorded and it was solved with the compensation of blood products. Further postoperative course was normal in surgery ward and therefore the patient was discharged in good condition. The patient was observed in the normal controls for the next 3 months, and no recurrence of the tumor has been recorded.

\section{Pathological findings}

HP analysis of tumor formation verified the proliferation of pleomorphic cells, together with an increased hiperhromatic nuclei and numerous mitotic activities . The large cells with multiple nuclei of malignant morphological features can be seen. Immunohistochemical analysis (vimentin +, CD68 +, S100 +, CEA, PanCK-, NF. Actin + / -, desmin-, SMA-, CD34-), prooved it to be a malignant fibrous histiocytoma. HP analysis of the snippets of surrounding tissue verifiedfragments of connective, muscle and adipose tissue in the absence of tumor proliferation.

\section{Discussion}

Malignant Fibrous Histiocytoma is a sarcoma of mesenchymalorigin affecting soft tissues of the body, particularly the extremities and retroperitoneum ${ }^{2}$. Rarely, it mayaffect intra-peritoneal organs ${ }^{8,9}$. Its occurrence has beenreported in almost all parts of the body including head and neck, intracranial, intra-abdominal organsand heart muscle. It is considered as the mostcommon soft tissue sarcoma of the adults, but mayoccur in children as well as infants. There are approximately 12.000 new adult sarcoma cases each year, encompassing seventy different histologic types of mesenchymal tumors that arise from bone, cartilage, fat, muscle, blood vessels, or other connective or supportive tissue ${ }^{10}$. MFH is an aggressive tumour with a high potential ofmetastasis to the other parts of the body. The vast majority of metastatic disease from sarcomas including MFH present as pulmonary disease (90\%). Involvement of extra-pulmonary sites is uncommon: lymph nodes $(10 \%)$, bone $(8 \%)$, liver $(1 \%)$. The current treatment ofchoice for primary malignant fibrous histiocytomas is surgical resection, which involves wide excision ofthe tumour with an aim for tumour free margins 10. Recurrenceof the tumour is not uncommon even when resectionmargins are tumour free. Metastasis may presentmonths or years after resection of the primary lesion.Treatment for metastatic disease is surgical where possible. Palliative surgery may be carried out if complete resectionis not possible. The role of adjuvant radiotherapy andchemotherapy is not clear in the case of retroperitonealand visceral sarcomas. There are studies that suggest noimprovement in overall survival after systemic chemotherapy $11,12,13$. Some advocate the use of chemoembolizationfor unresectable metastatic sarcomas, which canprovide durable tumour response ${ }^{14}$. Operative planning needs to detail carefully the extent of disease at the initial surgical treatment and more specifically to document the size and depth of the tumor with respect to muscle and deep fascia. Radioisotope scanning, computer tomographic scanning and arteriography are techniques that can assist the operative plans. Any surgeon who undertakes the excision of a soft-tissue mass should have the experience and technical ability to proceed with definitive ablation of the lesion. The surgical pathologist should be expected to render a definitive working tissuediagnosis.Radical surgical removal of the primary tumor isan essential first step, but that is not enough-thereis an urgent need for an effective postsurgical adjuvanttreatment program ${ }^{15}$.

Factors of prognostic importance in patients withsoft tissue sarcomas are histologic grade, site (proximal versus distal location), size, and lymph node involvement ${ }^{16}$. Lot of study demonstrates that the major prognostic factors for MFH are size and grade of the primarytumor. Most reports suggest that the prognosis associated with abdominal MFH is poorer than tumors in the extremities, due to late detection owing to location.

Bertonireported 78 cases of MFH "locatedand deeply seated in the extremities" and found theprognosis to be worse for tumors larger than $5 \mathrm{~cm}$ indiameter, tumors that recurred early (less than 1 year after surgery), and tumors that had inadequate surgicaltreatment (intralesional or marginal excision). Theoverall 5-year survival rate was only $36 \% 17$, 18 . Kearneyreported 167 cases of MFH from the Mayo Clinicand found the most important prognostic factors to bethe depth of the tumor and proximal versus distal location. Their study showed no difference 
in prognosis betweenthe different histologic subtypes ${ }^{18}$. In a review of 200 cases of MFH, Weiss and Enzinger found thatlarger and more deeply located tumors metastasizedmost frequently. Their analysis of MFHshowed that the 2-year survival rate with the storiform-pleomorphic type of MFH is $60 \%$ and the rate of metastases is $42 \%$. Myxoid tumors have low metastatic propensity (13\%, 10-year metastatic rate) compared to non-myxoid tumors $(40 \%, 10 \text {-year metastatic rate })^{5}$.

Depending on the stage of disease and the depth of invasion by the tumor, surgical resection is the treatment of choice. Radiotherapy, chemotherapy, and immunotherapy are other therapeutic modalities. Long term followup with regular chest X-rays and CT scans of the abdomen to detect tumor recurrence, metastasis and any lymph node involvement are mandatory.

\section{Literature}

1. Nurdjanah S, Bayupurnama P, Maduseno S, Ratnasari N. Abdominal malignant fibrous histiocytoma infiltrating stomach with Chilaiditi’s sign manifestation (a rare case report). Kobe J Med Sci 2007;53:119-24.

2. Peiper M, Zurakowski D, Knoefel WT, Izbicki JR. Malignant fibrous histiocytoma of the extremities and trunk: an institutional review. Surgery 2004;135:59-66.

3. Goldman SM, Hartman DS, Weiss SW: The varied radiographicmanifestations of retroperitoneal malignant fibroushistiocytoma revealed through 27 cases. J Urol (Balt)135:33-38, 1986

4. Fletcher $\mathrm{CD}$. The evolving classification of soft tissue tumours: an update based on the new WHO classification. Histopathology 2006;48(1):3-12. Current classification of MFH asundifferentiated pleomorphic sarcoma.

5. Weiss SW, Enzinger FM. Malignant fibrous histiocytoma: an analysis of 200 cases. Cancer 1978;41:2250-66.

6. Tierney JF, Mosseri V, Stewart LA, Souhami RL, Parmar MK. Adjuvant chemotherapy for soft-tissue sarcoma: review and meta-analysis of the published results of randomised clinical trials. Br J Cancer 1995;72:469-75.

7. Le Doussal V, Coindre JM, Leroux A. Prognostic factors for patients with localized primary malignant fibrous histiocytoma: a multicenter study of 216 patients with multivariate analysis. Cancer 1996; 77:1823-30.

8. Atmatzidis KS, Pavlidis TE, Galanis IN, Papaziogas BT, Papaziogas TB:Malignant fibrous histiocytoma of the abdominal cavity: report of a case.Surg Today 2003, 33:794-796.

9. Salemis NS, Gourgiotis S, Tsiambas E, Panagiotopoulos N, Karameris A,Tsohataridis E. Primary intra-abdominal malignant fibrous histiocytoma: ahighly aggressive tumor. J Gastrointest Cancer 2010, 41:238-242.

10. Jemal A, Siegel R, Ward E, et al. Cancer statistics. CA: a cancer journal for clinicians 2007;57(1):43-66. [PubMed: 17237035]

11. Edmonson JH, Ryan LM, Blum RH, Brooks JS, Shiraki M, Frytak S, et al.Randomized comparison of doxorubicin alone versus ifosfamideplus doxorubicin or mitomycin, doxorubicin and cisplatinagainst advanced soft tissue sarcomas. J Clin Oncol 1993,11:1269- 1275.

12. Casper ES, Christman KL, Schwartz GK, Johnson B, Brennan MF, BertinoJR. Edatrexate in patients with soft tissue sarcoma. Cancer1993, 72:766-770.

13. Wilson RE, Wood WC, Lerner HL, Antman K, Amato D, Corson JM, et al. Doxorubicin chemotherapy in the treatment of soft-tissuesarcoma - combined results of two randomized trials.Arch Surg 1986, 121:1354-1359.

14. Rajan DK, Soulen MC, Clark TW, Baum RA, Haskal ZJ, Shlansky-Goldberg RD, et al. Sarcomas metastatic to the Liver:Response and Survival after Cisplatin, Doxorubicin, Mitomy cin-C, Ethiodol, and Polyvinyl Alcohol ChemoembolizationJournal of Vascular and Interventional Radiology. 2001,12:187-193.

15. Michael M. Kearney, Edvard H. Soule, JohnC. Ivins:Malignant Fibrous Histiocytoma-A Retrospective Study of 167 Cases. Cancer 45167-178. 1980.

16. Rosenberg SA, Sutie HD, Baker LH. Sarcomas of soft tissues. In: DeVita VT, Hellman S, Rosenberg SA, eds. Principles and Practice of Oncology. Philadelphia: JB Lippincott, 1985; 1243-1291.

17. Bertoni F, Capanna R, Biagini R et al. Malignant fibrous histiocytoma of soft tissue: An analysis of 78 cases located and deeplyseated in the extremities. Cancer 1985; 56:356-367.

18. Kearney MM, Soule EH, Ivins JC, Malignant fibrous histiocytoma: A retrospective study of 167 cases. Cancer 1980; 45:167-178.

Autor za korespondenciju: Ass. dr sc dr Nebojša Mitrović Klinika za hirurgiju KBC Zemun 